\title{
Prevalence and morphological details of Nyctotherus periplanetae in the host Periplaneta americana, collected from Nashik District of Maharashtra
}

\author{
Sunil N. Bhamare ${ }^{1}$, Susheel V. Nikam ${ }^{2}$ and Bhimrao N. Jadhav ${ }^{3}$ \\ Sahebrao V. Pawar ${ }^{1}$ \\ ${ }^{1}$ Department of Zoology, K.R.A. College Deola Nashik, Maharashtra \\ ${ }^{2}$ Department of Zoology, Dr. B.A.M. University Aurangabad \\ ${ }^{3}$ Department of Zoology, Shri Muktanand College Gangapur Aurangabad (M.S.)
}

\begin{abstract}
Nyctotherus periplanetae is very common intestine dwelling ciliate in invertebrates. During the period of two years total number of 1842 intestinal samples of Periplaneta americana were checked. The percentage of prevalence of ciliates was found quite high and it was 57.77\% during the year 2007 and $60.75 \%$ in 2008.
\end{abstract}

Key words- Periplaneta, Intestine, Nyctotherus, Prevalence

\section{Introduction-}

The genus Nyctotherus Leidy, (1849) is belongs to Class Spirotrichea, Subclass Polymenophora, Order Clevelandellida (de Puytorac and Gain, 1976) and Family Nyctotheridae (Amero, 1972). It is first time reported by Leidy, (1849), in the millipede host. Later several forms were described by various authors in various hosts. Grasse (1928) suggested the splitting up of this genus Nycyotherus and Nyctotheroides to accommodate forms with and without a karyophore respectively. Corliss (1961) elevated these subgenera to a generic level, Amero and Sena (1967), they also suggested the splitting up of this genus into three subgenera as Recurviperistomatus, Curviperistomatus and Nyctotherus on the nature of cytopharyanx. They listed 33 species of this genus Nyctotherus. Early workers like Puytorac et al. $(1967,1968)$ Albaret $(1968,1970)$ and Earl $(1970)$ also reported different Nyctotherus species and related new genus like Metanyctotherans, parasicuoohora and Sicuophore Earl (1972) also established a new superfamily Plagiotomoidae to place different genus (above described genera) and also named two families, Plagiotomidae (Butschli, 1887) and Clevelandellidae (kidder 1938)

Corliss (1979) described Nyctotherus in class Polyhymenophora (Jankowski 1967), Subclass Spirotrichea Butschli, (1889), Order Heterotrichida Stein (1859), and Suborder - Clevelandellina (de Puytorac and Grain (1976) with family Nyctotheridae Amero (1972).

According to recent literature, Bhatia et al., (1936) has given a key for the identification of the species of the genus Nyctotherus.

- Cytopharynx not reaching beyond the middle of the body.

- Cytopharynx directed obliquely backwards and not reaching the middle.

- Cytopharynx shorter than the pristome.

(i) Body bean shaped with concave right margin. Length 26 to $28 \mu$ Macronucleus globular and contains 4-5 chromatin masses.

N. faba (Schaudinn)

(ii) Body peculiar shaped. Length $40-50 \mu$; macronucleus globular with 4 chromatin masses.

N. africanus (Castellani)

(iii) Body ovoid, narrower and rounded anteriorly and broader and stunted posteriorly. Length $90-400 \mu$, macronucleus bean shaped.

$N$. giganteus (Kranse)

(iv) Body egg shaped, Length 100 - 140 $\mu$. Macronucleus egg shaped.

N. velox (Leidy)

(v) Body ovoid. Cytopharynx slightly curved length $60-70 \mu$. Macronucleus ovoid or slightly horse - shoe shaped.

N. termitis (Dobell)

(vi) Body reniform. Cytopharynx slightly curved like a semicircle, with a diverticulum at its junction with the cytostome. Length 120 - $170 \mu$ Macronucleus reniform of horse shoe shaped.

N. pappillatus (Dobell)

(vii) Cytopharyanx reaching beyond the middle of the body, cytopharyanx shorter that the transverse diameter of the body. Cytopharynx slightly curved with the concavity directed forwards. Body elongated length $170 \mu$. Macronucleus elongated oval. 
N. kempi (Ghosh)

(viii) Cytopharynx broadly curved posteriorly. Body is oviform, Length is $30-120 \mu \mathrm{m}$. Macronucleus is discoidal.

\section{N. haematobius ENTZ}

(ix) Body ovoid. Anterior end narrow, posterior end wide but tapering to a point length 112 to $152 \mu$ for small forms and 200 - $268 \mu$ for large ones macronucleus tetraraheral.

N. piscicola (Daday)

(x) Body egg shaped length $100 \mu$. Macronucleus egg shaped.

N. duboisii (Kunstler)

(xi) Body kidney shaped, length $160 \mu-180 \mu$ (Bezz) or 77 to $11 \mu$ (Stein) breadth $2 / 3-3 / 4$ of the body length. Macronucleus kidney shaped.

N. cordiformis (Stein).

\section{Material and Methods-}

The hosts were collected from different villages of Nashik dist (Deola, Nandgaon; Surgana, Kalwan Satana) of Maharashtra state. Due care was taken and the hosts were collected in moist soil with decaying leaves were present and the temperature was maintained by using ice bags around them. Mostly the hosts were collected during morning and evening. Due to the great variability in temperature and humidity the millipedes were only available in the period of June to November. Especially the were found abundant in rainy season.

The faecal samples were obtained from different parts of host intestine like fore gut mid gut and hind gut. The drops of faecal samples were observed under 45X and then 100X under microscope. Rapid movements of ciliates make it difficult to identify ciliate species. To immobilize their movements, methyl cellulose solution was used. Methyl cellulose has been found too many advantages, as it arrest the movement, ciliates can be identified by their appearance. For the preparation of permanent slides, the positive samples were stained by tungusto-phosphoric acid haematoxylin.

The Dry silver impregnation was also used to study infraciliature of the ciliates. The species identification has been made mainly on the basis of arrangement of cilia, size and shape of body and structure of macro, micronucleus cyto-pharynx and cytopyge.

\section{The systematic position of ciliates in cockroach}

Phylum: - Ciliophora.

Class: - Spirotrichea.

Subclass: - Polymenophora

Order: - Clevelandellida - de Puytorac and Gain, (1976)

Family: - Nyctotheridae - Amorao, (1972)

Genus: - Nyctotherus - Leidy, (1849)

Species:-N. periplanetae, Lalpotu, (1976), Shaikh (2006)

\section{Percentage of prevalence of ciliate Nctotherus periplaneta}

During the period of two years (Jan.2007 to Dec.2008) a total 1842 number of cockroaches were examined. 1091 of these were positive for ciliate infection.

In the first year (Jan.2007 to Dec.2007) total 940 cockroaches were examined and 543 of these were positive. The percentage of prevalence was being $57.77 \%$.

In the second year (Jan.2008 to Dec.2008) total 902 cockroaches were examined and 548 of these were positive. The percentage of prevalence was being $60.75 \%$.

A month wise analysis in first year (Jan.2007 to Dec.2007) shows the maximum percentage of prevalence during September and October $(70.59 \%, 75.82 \%)$, lowest in May (43.18\%) and moderate in remaining months. In second year (Jan.2008 to Dec.2008) the maximum percentage of prevalence was recorded during July to September $(73.44 \%, 74.38 \%, 73.03 \%)$, lowest in March and April (39.02\%, 35.90\%) and moderate in remaining months.

The pattern in both the years suggests that the peak is soon after the monsoon rain. The percentage then gradually reduces at the end of the winter months and lowest with the onset of summer. The details of the number of animals examined and the month wise prevalence is shown in Table No. 1 and 2. 
Prevalence and morphological details of Nyctotherus periplanetae in the host Periplaneta americana,

TABLE 1

SHOWING THE MONTHWISE PREVALENCE OF CILIATES IN COCKROACH

(Periplaneta americana) during the period from Jan.2007 To Dec.2007

\begin{tabular}{|c|c|c|c|c|}
\hline $\begin{array}{c}\text { Sr } \\
\text { No }\end{array}$ & Months & $\begin{array}{c}\text { Total No.of } \\
\text { Host } \\
\text { Examined }\end{array}$ & $\begin{array}{c}\text { No.of } \\
\text { +ve Hosts }\end{array}$ & $\begin{array}{c}\text { \% of Total } \\
\text { Prevalence }\end{array}$ \\
\hline 1 & Jan-07 & 94 & 46 & 48.94 \\
\hline 2 & Feb-07 & 80 & 39 & 48.75 \\
\hline 3 & Mar-07 & 75 & 35 & 46.67 \\
\hline 4 & Apr-07 & 45 & 21 & 46.67 \\
\hline 5 & May-07 & 44 & 19 & 43.18 \\
\hline 6 & Jun-07 & 56 & 29 & 51.79 \\
\hline 7 & Jul-07 & 123 & 69 & 56.10 \\
\hline 8 & Aug-07 & 107 & 72 & 67.29 \\
\hline 9 & Sep-07 & 85 & 60 & 70.59 \\
\hline 10 & Oct-07 & 91 & 69 & 65.82 \\
\hline 11 & Nov-07 & 89 & 57 & 52.94 \\
\hline 12 & Dec-07 & 51 & 27 & $\mathbf{5 7 . 7 7}$ \\
\hline & Total & $\mathbf{9 4 0}$ & $\mathbf{5 4 3}$ & \\
\hline
\end{tabular}

TABLE 2

SHOWING THE MONTHWISE PREVALENCE OF CILIATES IN COCKROACH

(Periplaneta americana) during the period from Jan.2008 To Dec.2008

\begin{tabular}{|c|c|c|c|c|}
\hline $\begin{array}{c}\text { Sr } \\
\text { No }\end{array}$ & Months & $\begin{array}{c}\text { Total No.of } \\
\text { Host } \\
\text { Examined }\end{array}$ & $\begin{array}{c}\text { No.of } \\
+ \text { +ve Hosts }\end{array}$ & $\begin{array}{c}\text { \% of Total } \\
\text { Prevalence }\end{array}$ \\
\hline 1 & Jan-08 & 79 & 41 & 51.90 \\
\hline 2 & Feb-08 & 55 & 22 & 40.00 \\
\hline 3 & Mar-08 & 41 & 16 & 39.02 \\
\hline 4 & Apr-08 & 39 & 14 & 35.90 \\
\hline 5 & May-08 & 46 & 23 & 50.00 \\
\hline 6 & Jun-08 & 64 & 41 & 64.06 \\
\hline 7 & Jul-08 & 128 & 94 & 73.44 \\
\hline 8 & Aug-08 & 121 & 90 & 74.38 \\
\hline 9 & Sep-08 & 89 & 65 & 73.03 \\
\hline 10 & Oct-08 & 71 & 42 & 59.15 \\
\hline 11 & Nov-08 & 72 & 43 & 59.72 \\
\hline 12 & Dec-08 & 97 & 57 & 58.76 \\
\hline & Total & $\mathbf{9 0 2}$ & $\mathbf{5 4 8}$ & $\mathbf{6 0 . 7 5}$ \\
\hline
\end{tabular}



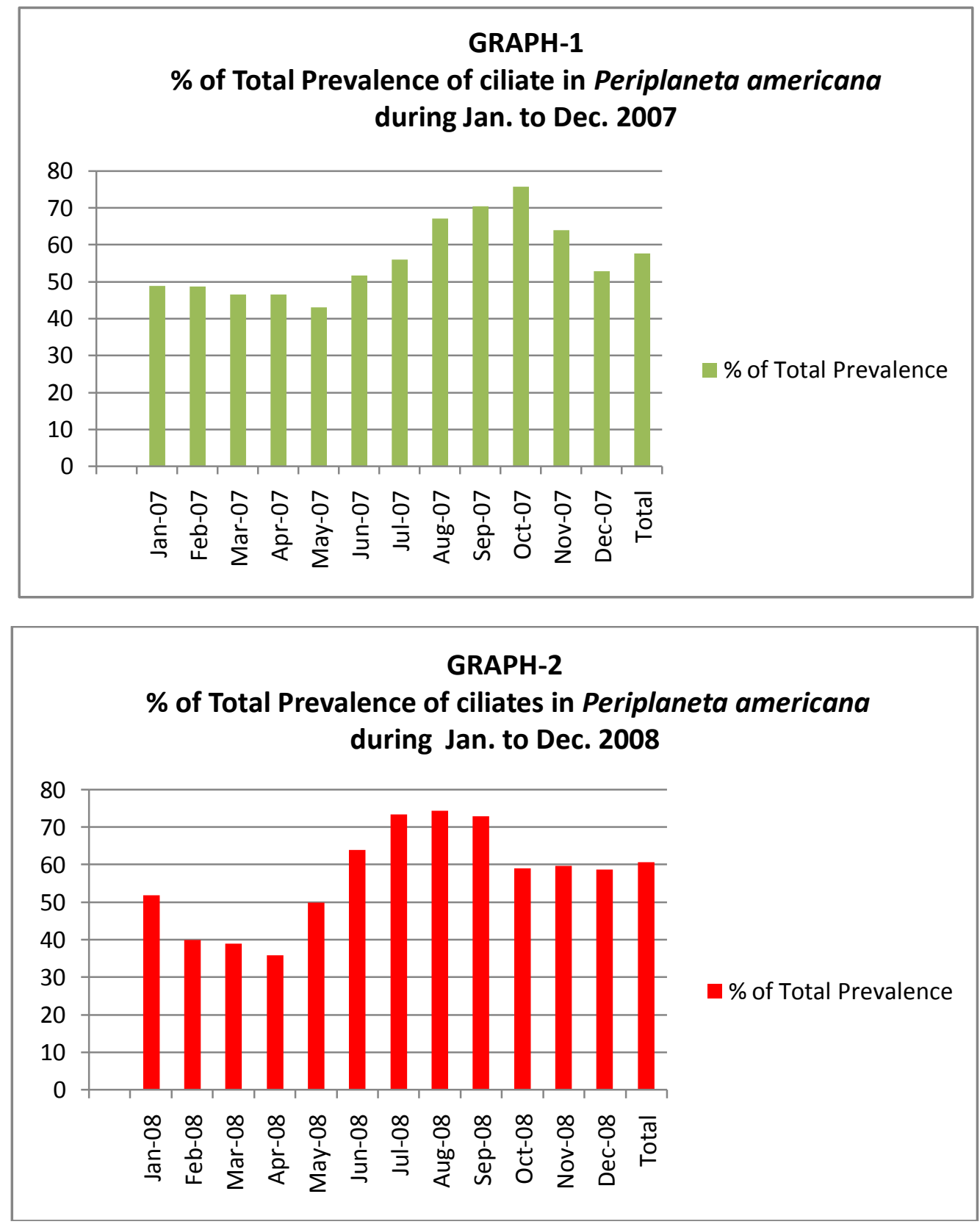

\section{Morphology of Nyctotherus periplanetae}

The shape of the body is oval and slightly narrow at the anterior end. The posterior end is broader than the anterior one. It is covered by a thick and stiff cuticle that bears the numerous fine cilia. It measures 100 to $175 \mu$ in length and 95 to $150 \mu$ is width. The peristomal groove starts from the anterior region of the body and situated in the middle of the ventral surface and open in to straight cytopharynx. The peristome is about 15 to $19.5 \mu$. The cytopharynx is straight, tubular, slightly bent at the tip, curved in some cases. It is situated at the dorsal side, somewhat posterior part of the body, just behind the macronucleus. The tip of the cytopharynx is comma shaped. The cytopharynx is about $87.5 \mu$ to $112.5 \mu$ in length and 7.5 to $12 \mu$ is width. The dorsal cilia in peristomal groove and cytopharynx are stouter and longer than the body cilia.

The macronucleus is granular and irregular in shape. It is mostly biconcave but variable forms are seen. They are bowl shape, somewhat triangular, and semi ovoid. It is about 15 to $32.5 \mu$ in length and 32.5 to $75 \mu$ is width. It is surrounded a membrane that some denominate suspensorium, which adheres to the dorsal cuticle at an upper level than to the ventral one. So the nucleus and its suspensorium separate the ciliate in two well defined zones. An anterior and smaller one filled with darker particles and the bigger posterior one full with lots of clear granules. The micronucleus is situated on the antero-ventral side of the macronucleus. A large contractile vacuole about 17.5 to $18.5 \mu$ in diameter usually appears near the cytopyge. The cytopyge is slit like and always located at the posterior end of the organism. 


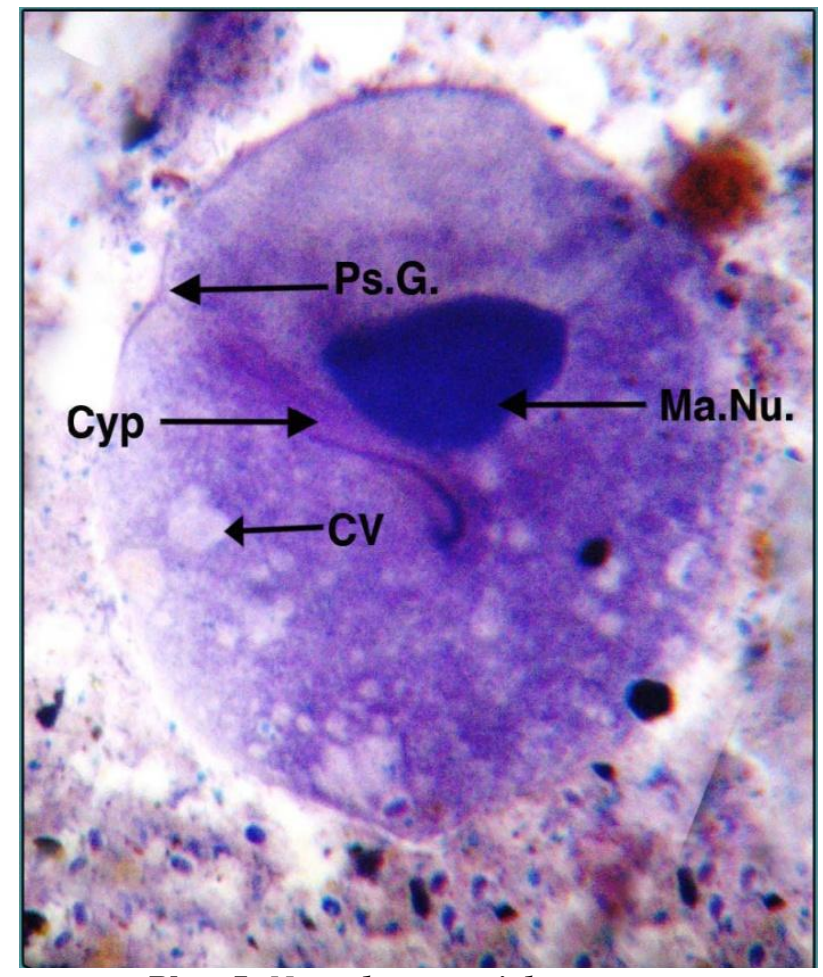

Plate I- Nyctotherus periplanetae

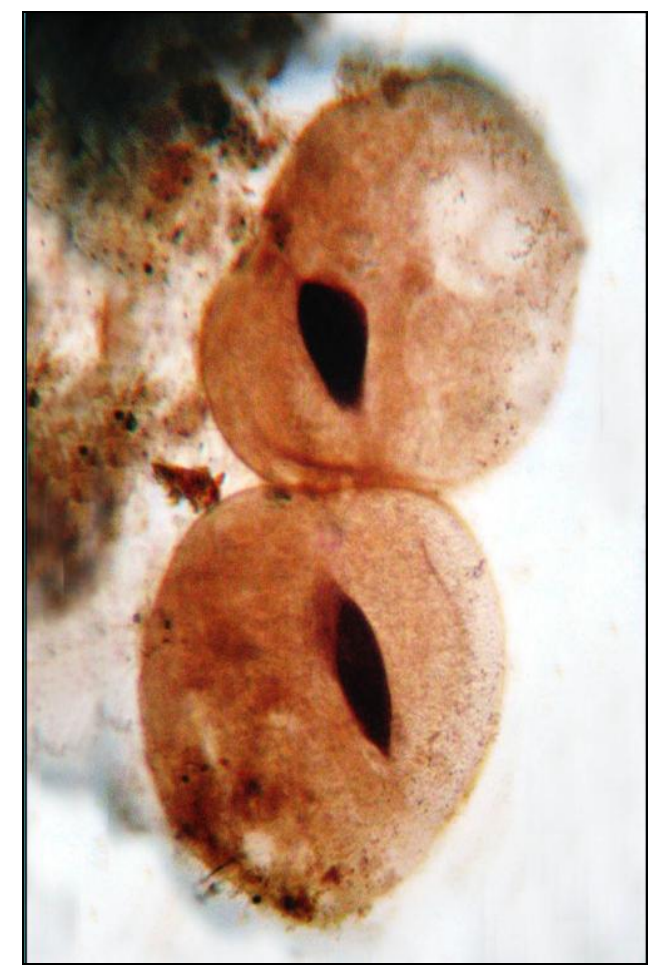

Plate II- N. periplanetae conjugation

\section{Comments-}

The present author agrees with the new species $N$. periplanetae described by Lalpotu (1976) and same species redescribed by T.T. Shaikh (2006) and Bhandari, (2010). All the morphological characters are similar to previously described species, only some minor differences are found.

After the comparison of the body dimension it is seen that the Present species is largest in all. Cytopharynx is beak like in species of Lalpotu (1976), and comma shaped in the species of Bhandari (2010), cytopharynx in the present species is comma Shaped, matches with the species of Bhandari. Cytopyge is oval in case of Lalpotu and T.T. Shaikh; it is slit like in present species, again matches with the cytopyge of species of Bhandari. So species is considered as N. periplanetae and redescribed here. See Table No. 3.

Table 3- Comparison of the present species with the species of Nyctotherus

\begin{tabular}{|c|c|c|c|c|c|}
\hline \multirow{2}{*}{$\begin{array}{l}\text { Sr. } \\
\text { No. }\end{array}$} & No. Of species & 1 & 2 & 3 & 4 \\
\hline & Particulars & $\begin{array}{l}\text { N. periplanetae n. } \\
\text { sp. } \\
\text { Lalpotu (1976) }\end{array}$ & $\begin{array}{l}\text { N. periplanetae } \\
\text { T. T. Sheikh } \\
(2005)\end{array}$ & $\begin{array}{l}\text { N. periplanetae } \\
\text { Bhandari }(2010)\end{array}$ & $\begin{array}{l}\text { N. periplanetae } \\
\text { Present author }\end{array}$ \\
\hline 1 & $\begin{array}{l}\text { Body shape and } \\
\text { dimensions }\end{array}$ & $\begin{array}{l}\text { Ovoidal, anterior } \\
\text { end slightly } \\
\text { narrow, posterior } \\
\text { end broad } \\
\text { L- } 78.8 \text { to } 122.9 \mu \\
\text { W- } 50.4 \text { to } 91.4 \mu\end{array}$ & $\begin{array}{l}\text { Oval shape, } \\
\text { somewhat laterally } \\
\text { compressed } \\
\text { L- } 61.00 \text { to } 110 \mu \\
\text { W- } 45 \text { to } 65 \mu\end{array}$ & $\begin{array}{l}\text { Oval, slightly } \\
\text { narrow at anterior } \\
\text { end } \\
\text { L- } 93.07 \text { to } \\
111.35 \mu \\
\text { W- } 47.67 \text { to } \\
81.73 \mu\end{array}$ & $\begin{array}{l}\text { Oval, slightly } \\
\text { narrow at anterior } \\
\text { end. The posterior } \\
\text { end shows pointed } \\
\text { projection } \\
\text { L- } 100 \text { to } 175 \mu \\
\text { W- } 95 \text { to } 150 \mu\end{array}$ \\
\hline 2 & $\begin{array}{l}\text { Peristomal groove } \\
\text { or peristome }\end{array}$ & $\begin{array}{l}\text { Behind anterior } \\
\text { end } \\
\text { Middle of the } \\
\text { ventral surface }\end{array}$ & $\begin{array}{l}\text { Behind anterior } \\
\text { end }\end{array}$ & $\begin{array}{l}\text { Start at anterior } \\
\text { end } \\
\text { Middle of the } \\
\text { ventral surface }\end{array}$ & $\begin{array}{l}\text { Behind anterior } \\
\text { end } \\
\text { Peristome is } \\
\text { middle of the } \\
\text { ventral surface, } 15 \\
\text { to } 19.5 \mu \text { in length }\end{array}$ \\
\hline 3 & Cytopharynx & $\begin{array}{l}\text { Straight, beak like } \\
\text { and bent at the tip }\end{array}$ & $\begin{array}{l}\text { Straight, slightly } \\
\text { bent at the tip }\end{array}$ & $\begin{array}{l}\text { Straight and } \\
\text { comma shaped at } \\
\text { anterior tip }\end{array}$ & $\begin{array}{l}\text { Straight, tubular, } \\
\text { comma shaped at } \\
\text { anterior tip } \\
\mathrm{L}-87.5 \mu \text { to } 112.5 \\
\mu \\
\mathrm{W}-7.5 \text { to } 12 \mu\end{array}$ \\
\hline
\end{tabular}




\begin{tabular}{|l|l|l|l|l|l|}
\hline $\mathbf{4}$ & Macronucleus & $\begin{array}{l}\text { Variable in shape } \\
\text { mostly bowl like } \\
\text { or concave }\end{array}$ & $\begin{array}{l}\text { Irregular shape } \\
\text { fusiform bowl and } \\
\text { granular or } \\
\text { biconvex }\end{array}$ & $\begin{array}{l}\text { Variable in shape, } \\
\text { bowl shape }\end{array}$ & $\begin{array}{l}\text { Bowl shaped, } \\
\text { biconvex } \\
\text { L- } 15 \text { to } 32.5 \mu \\
\text { W- } 32.5 \text { to } 75 \mu\end{array}$ \\
\hline $\mathbf{5}$ & Micronucleus & $\begin{array}{l}\text { Antero-ventral } \\
\text { side of } \\
\text { macronucleus }\end{array}$ & $\begin{array}{l}\text { Antero-ventral } \\
\text { side of the } \\
\text { macronucleus }\end{array}$ & $\begin{array}{l}\text { Antero-ventral } \\
\text { side of the } \\
\text { macronucleus }\end{array}$ & $\begin{array}{l}\text { Antero-ventral } \\
\text { side of the } \\
\text { macronucleus }\end{array}$ \\
\hline $\mathbf{6}$ & $\begin{array}{l}\text { Contractile } \\
\text { vacuoles }\end{array}$ & Single, large & Single, large & Single, large & $\begin{array}{l}\text { Single, large, } \\
\text { rounded, 17.5 to } \\
18.5 \mu \text { in } \\
\text { diameter }\end{array}$ \\
\hline $\mathbf{7}$ & Cytopyge & Oval shape & Oval shape & Slit like shape & Slit like \\
\hline $\mathbf{8}$ & Host & $\begin{array}{l}\text { Periplaneta } \\
\text { americana }\end{array}$ & $\begin{array}{l}\text { Periplaneta } \\
\text { americana }\end{array}$ & $\begin{array}{l}\text { Periplaneta } \\
\text { americana }\end{array}$ & $\begin{array}{l}\text { Periplaneta } \\
\text { americana }\end{array}$ \\
\hline $\mathbf{9}$ & Locality & $\begin{array}{l}\text { Parbhani dist. } \\
\text { (M.S.) }\end{array}$ & $\begin{array}{l}\text { Aurangabad dist. } \\
\text { (M.S.) }\end{array}$ & $\begin{array}{l}\text { Aurangabad dist. } \\
\text { (M.S.) }\end{array}$ & Nashik dist. (M.S.) \\
\hline
\end{tabular}

\section{References-}

[1]. Algamaliev, (1973): Observtion sur des nycthotherus des genres sicuopbora de puytorac and Grain Mestasicuphora gen N.et Parascicuophora Albert cilie parasites de batracienus anoeres

[2]. Amero A and Sena, S. (1967a): Lista provisora des species do genero "Nyctotherus" Leidy, 1849 (Ciliatea Heterotrichida) Ates soc. Biol. Rio de Janeiro; 10(6): 149-151.

[3]. Amero, A. and Sena, S. (1967a): Sobre a sistematica do genero: Nyctotherus" Leidy, 1849 (Ciliatea, Heterotrichida). Ibid; 11 (3): 119-120 J.protozol; 20: 51-57.

[4]. Amoji, S. D. and Rodgi, S. S. (1970): A ciliates parasites Nyctotherus georgei n.sp.from the millipede Gongylorrhus sp. The Indian Zoologist, 1:81-86.

[5]. Bhandari J. C. (2010): Studies on some Ciliate and Gregarine parasites of Annelida and Arthropoda

[6]. Bhatia, B. L. (1936): The Fauna of British India, Protozoa, Ciliophora. Taylor and Francis, London.

[7]. Bhatia, B. L. And Gulati A. N. (1972): On some parasitic ciliates from Indian frogs,toads earthworms and cockroaches. Arch Protistenk; 57: 85-120.

[8]. Corliss, J. O. (2001): Two most remarkable amoeba men: Joseph Leidy (1823-1891) of Philadelphia and Eugene Penard (18551954) of Geneva Protist; 152: 69-85.

[9]. Grasse,P. P. (1928): sur quelques Nyctotheres (Infusories heteroriches) nouveaux ou peu connus . Annuls Protist; 1: 55-98.

[10]. Klein, B. M. (1958): The "dry" silver method and its proper use. J. Protozool. 5:99.

[11]. Kudo, R. R. (1977): Protozoology $5^{\text {th }}$ ed. Springfield, III: Chane, C.C. Thomas (1774)

[12]. Lalpotu (1976): Observation on some Protozoan Parasites of invertebrates, Ph. D. thesis of Dr. B.A.M. University Aurangabad.

[13]. Leidy J. (1949): Nyctotherus.a new genus of polygastrica, allied to plescoma.proc. Acad. Nat. Sci. Philad; 4 : 233.

[14]. Lynn, D. H. and Small, E. B. (2000): Phylum Ciliophora In An illustrated guide to the protozoa.2-nd ed.(Eds. Lee J. J. Hunter S. H. and Bovee E. C.) Allen press, Lawrence, 371-655.

[15]. Puytorac, P. de, (1967): Observations cytologique sur les Nyctotherus des generes Nyctotherus Leidy et Prosicuophora n. gen. ciliates parasites de batraciens Anoures du Gabon. Biol. Gabon; 3(3): 223-243.

[16]. Rosenberg, L. E. (1937): The Neuromotor system of Nyctotherus hyiae. Ibid; 41: 249-276.

[17]. Rothschild, L.J. (2004): Introductory Remarks: Protozoology (Protistology) at the dawn of the $21^{\text {st }}$ century. J. Eukaryotic. Microbiol. 51(1):3-7.

[18]. Seethalakshmi Ayer (1979): Studies on Some Parasitic Protozoa from some Invertebrates, Ph. D. thesis of Dr. B. A. M. University Aurangabad.

[19]. Sergei I. Fokin, (2004): A brief history of ciliate studies (late XVII _ the first third of the XX century) Protistology 3 (4), 283_296 (2004).

[20]. Sheikh, T. T. (2006): Studies on some free living and parasitic ciliates Ph. D. thesis of Dr. B. A. M. University Aurangabad. 